\title{
RANGIRANJE LOGISTIČKIH PROJEKATA NA OSNOVU RIZIKA PRIMENOM AHP METODOLOGIJE
}

\author{
Milan Stojanović ${ }^{1}$, \\ Predrag Popović1, \\ Željko Milovanović ${ }^{2}$
}

\author{
1 Univerzitet Singidunum, \\ Danijelova 32, \\ Beograd, Srbija \\ 2JKP „Vodovod” Zaječar, \\ Bulevar dr Zorana Đinđića 5, \\ Zaječar, Srbija
}

Correspondence:

Milan Stojanović

e-mail:

milan.stojanovic.13@singimail.rs

\begin{abstract}
Rezime:
Savremeni uslovi poslovanja podrazumevaju veliku konkurenciju. U skladu sa tim, za uspeh na turbulentnom tržištu potrebno je obavljati poslove bolje i efikasnije od konkurencije. Logistika predstavlja jedan od najvažnijih celina od koje u velikoj meri zavisi uspeh određenog preduzeća na tržištu. Logistički projekti predstavljaju moderno sredstvo za obavljanje logističkih aktivnosti. Ovi projekti su često veoma brojni i zahtevaju adekvatno upravljanje. Veliki problem u upravljanju logističkim projektima predstavljaju rizici. Predmet istraživanja rada ogleda se u rangiranju logističkih projekata na osnovu rizika primenom AHP metode i softverskog paketa Expert Choice 11. Cilj samog istraživanja podrazumeva rangiranje logističkih projekata na osnovu definisanih rizičnih događaja, utvrđivanje globalnog nivoa rizika u logističkim projektima i rangiranje na osnovu istog.
\end{abstract}

Ključne reči:

rizik, logistički projekti, upravljanje, AHP metoda, softver Expert Choice 11.

\section{UVOD}

Logistika predstavlja veoma važan deo određenog privrednog društva. Od uspeha logističke funkcije umnogome zavisi celokupan uspeh preduzeća. Logistika preduzeća predstavlja funkciju upravljanja preduzećem koja ima za cilj da već tradicionalnim vrednostima dobara, kao što su tip proizvoda, kvalitet, cena, doda nove vrednosti. Pored toga, cilj logistike je raspoloživost traženih dobara na mestu i u momentu u kome se manifestuje potreba potrošača za tim dobrima [1].

Ciljevi logistike preduzeća ostvaruju se kroz realizaciju logističkih projekata. Manipulacija i transport dobara kroz privredni subjekt veoma je kompleksan posao, te često zahteva odvijanje velikog broja logističkih projekata $\mathrm{u}$ isto vreme.

Usled velikog broja logističkih projekata koji se odvijaju u preduzeću, potrebno je istima upravljati na optimalan način. Jedan od najvećih problema realizacije logističkih projekata jeste prisustvo rizika i rizičnih događaja. U cilju dostizanja kompanijskih ciljeva, potrebno je utvrditi nivo rizika kod pojedinačnih projekata i izvršiti rangiranje na osnovu visine rizika. 


\section{UPRAVLJANJE PROJEKTNIM RIZICIMA}

Kod analiziranja upravljanja projektnim rizicima, potrebno je najpre definisati rizik. On se u literaturi veoma često različito definiše. U užem smislu, rizik predstavlja opasnost gubitka ili štete. Sagledavajući širi smisao, rizik opisuje mogućnost drugačijeg ishoda od onog koji se očekivao. Rizik predstavlja šansu da se dogodi nešto što će imati uticaj na ciljeve poslovanja [2].

Na osnovu savremenih shvatanja, svaki projekat sadrži elemente poslovnog procesa. Pošto se realizuje u budućnosti, on u sebi sadrži odgovarajući rizik i neizvesnost. Upravljanje rizikom projekta predstavlja složen proces multidisciplinarnog karaktera koji uključuje poznavanje menadžmenta, matematike, ekonomije i psihologije [3].

Upravljanje projektnim rizicima predstavlja izuzetno značajan deo celovitog procesa upravljanja jednim projektom, koji može značajno da utiče na ukupne rezultate projekta. Upravljanje rizicima u projektu predstavlja veoma složen upravljački koncept koji se sastoji od skupa relevantnih procesa, čijom se realizacijom ostvaruje ukupan proces upravljanja rizicima na projektu [4].

Upravljanje rizikom u projektu predstavlja kompleksan proces koji obuhvata stalnu i sistematsku identifikaciju, predviđanje i procenjivanje faktora rizika, a zatim pripremu i planiranje odbrambenih akcija i reakcija koje mogu doprineti smanjenju rizika. Proces upravljanja rizikom u projektu obuhvata pronalaženje preventivnih mera radi smanjenja rizika, koji mogu nastati u realizaciji određenog projekta [4].

Jedan od najvažnijih segmenata upravljanja rizika jeste određivanje veličine rizika i upoređivanja projekata na osnovu veličine rizika. Metode procene i uticaja pojave rizika, koji može da izazove određeni gubitak na posmatranom projektu, predstavljaju postupke kojima se meri veličina rizika. Ocene veličine rizika projekta zavise od velikog broja faktora [3]. Prilikom odabira metode za određivanje veličine rizika u projektima potrebno je sagledati sve faktore i odabrati najpogodniju metodu za date uslove određivanja veličine rizika.

\section{SOFTVERSKA PODRŠKAAHP METODOLOGIJI}

Softverska rešenja za podršku odlučivanju predstavljaju informacione sisteme koji su slični i komplementarni standardnim informacionim sistemima i imaju za cilj da podržavaju, uglavnom, poslovne procese donošenja odluka. Sistemi za podršku odlučivanju predstavljaju simbiozu informacionih sistema, primene niza funkcionalnih znanja i tekućeg procesa donošenja odluka. Ovi sistemi su interaktivni računarski sistemi koji imaju zadatak da pomognu menadžerima ili donosiocima odluka da identifikuju, strukturiraju i reše polustrukturirane i nestrukturirane probleme, ali i da naprave izbor među alternativama [5].

Neke od prednosti koje pruža softverska podrška odlučivanju jesu brža, jeftinija i kvalitetnija pomoć korisniku da lakše manipuliše podacima i rezultatima. Važno je da se sagledavanje i rešavanje problema odlučivanja postiže na transparentan način [6].

U ovom slučaju, potrebno je pronaći adekvatnu softversku podršku za AHP metodologiju. U cilju jednostavnijeg rešavanja problema rangiranja projekata na osnovu rizika primenom AHP metode, koristićemo softver Expert Choice [7].

Expert Choice je jedan od najefikasnijih alata za rešavanje problema višekriterijumskog odlučivanja. On omogućuju what if analizu pri strateškom planiranju proračuna projekata. Softver je u potpunosti prilagođen primeni AHP metode i podržava sve potrebne korake. Expert Choice dozvoljava strukturiranje problema i upoređivanje alternative i kriterijumima u parovima na više načina. Pored toga, on poseduje mogućnost sprovođenja analize osetljivosti pomoću jednostavne interaktivne razmene težina kriterijuma i alternative, ali i grafove za odličnu vizuelizaciju dobijenih rezultata [5].

Pomenuti softver podržava praktično neograničen broj kriterijuma i potkriterijuma, i u potpunosti implementira Analitički hijerarhijski proces Tomasa Satija. U okruženju softvera Expert Choice, izgradnja modela predstavlja direktan proces. Expert Choice podržava ispitivanje konzistentnosti pri vrednovanju kriterijuma i alternativa prema definisanoj hijerarhiji, tako da se lako može pratiti kako promene prioriteta kriterijuma utiču na rangove alternativa [8].

\section{METODOLOGIJA ISTRAŽIVANJA}

AHP je napredna metodologija višekriterijumske analize, koja je strukturirana od strane Tomasa Satija. Ona omogućava analizu hijerarhijski uređenih elemenata odlučivanja. AHP razlaže složeni problem u hijerarhiju, gde je cilj na vrhu, a kriterijumi i alternative na nižim nivoima. Pored toga, postoje i hijerarhije sa potkriterijumima. Međusobnim poređenjem u odnosu na viši cilj vrši se rangiranje kriterijuma, a zatim se na isti način vrednuju alternative i rangiraju međusobnim poređenjem u odnosu na svaki od kriterijuma na višem nivou hijerarhije [6]. 
Proces realizacije AHP metode obuhvata četiri osnovne faze: [5]

- Strukturiranje problema;

- Prikupljanje podataka;

- Ocenjivanje relativnih težina;

- Određivanje rešenja problema.

Početna faza realizacije AHP metode podrazumeva strukturiranje problema. U cilju strukturiranja problema, potrebno je definisati rizične događaje i broj projekata koji se upoređuju. U ovom slučaju, biće rangirano tri projekata na osnovu deset kriterijuma. Struktura problema odlučivanja prikazana je na Slici 1.

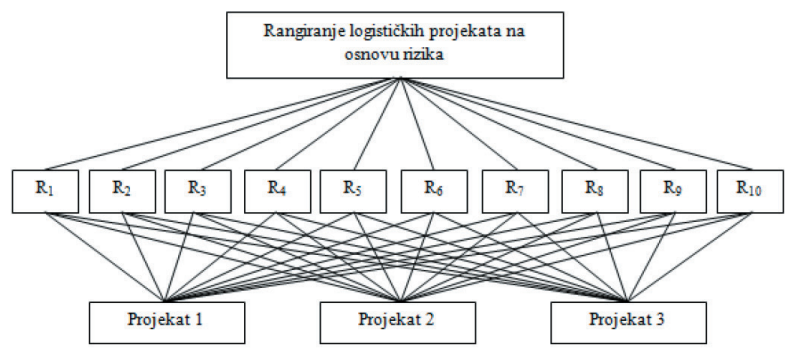

Slika 1. Hijerarhijska struktura problema odlučivanja

Druga faza primene AHP metode u rangiranju logističkih projekata na osnovu rizika podrazumeva prikupljanje podataka. Podaci o problemu odlučivanja prikupljeni su od relevantnih osoba za rangiranje projekata na osnovu rizika.

Sledeća faza je faza ocenjivanja relativnih težina. Naime, u ovoj fazi biće izvršeno međusobno upoređivanje rizičnih događaja i određivanje težinskih koeficijenata, ali i upoređivanje projekata na osnovu svakog rizičnog događaja ponaosob. Ocenjivanje će biti izvršeno od strane menadžera logistike i menadžera upravljanja rizikom.

Poslednja faza podrazumeva određivanje rešenja problema. U ovoj fazi biće izvršeno rangiranje razmatranih logističkih projekata na osnovu definisanih rizičnih događaja.

\section{REZULTATI I DISKUSIJA}

Kompanija koja se bavi distributerstvom planira da izvrši rangiranje logističkih projekata na osnovu rizika. Na osnovu mišljenja stručnih lica iz preduzeća, najveći uticaj na rezultate preduzeća imaju tri logistička projekta. U skladu sa tim, pomenuti logistički projekti ući će u završnu fazu rangiranja.
Prilikom rangiranja projekata na osnovu rizika, potrebno je postojanje određenih rizičnih događaja na osnovu kojih se vrši upoređivanje alternativa.

U cilju definisanja kriterijuma, kontaktirani su stručnjaci iz organizacije, uzeta iskustva kompanija slične delatnosti i pretražena naučna literatura. Iz pomenutih izvora preuzet je veliki broj kriterijuma.

Nakon toga, organizovan je sastanak na kome je izvršeno ocenjivanje rizičnih događaja logističkih projekata. Deset najbolje ocenjenih rizičnih događaja prikazani su u Tabeli 1.

\begin{tabular}{|c|c|}
\hline Obeležje & Rizični događaj \\
\hline $\mathrm{R}_{1}$ & $\begin{array}{l}\text { Iznenadne promene u planu } \\
\text { proizvodnje (pogrešna procena } \\
\text { funkcije marketinga i prodaje, izraženo } \\
\text { povećanje robe na zalihama) }\end{array}$ \\
\hline $\mathrm{R}_{2}$ & $\begin{array}{l}\text { Kvarovi tehničkih sredstava (kvar } \\
\text { sredstava unutrašnjeg transporta) }\end{array}$ \\
\hline $\mathrm{R}_{3}$ & $\begin{array}{l}\text { Iznenadno povećanje potražnje } \\
\text { (prenapregnutost logističkog sistema usled } \\
\text { angažovanja dodatnih ljudskih i tehničkih } \\
\text { resursa) }\end{array}$ \\
\hline $\mathrm{R}_{4}$ & $\begin{array}{l}\text { Loša komunikacija (nekontrolisana } \\
\text { komunikacija, ključne interesne grupe nisu } \\
\text { upoznate sa napredovanjem } \\
\text { logističkog projekta) }\end{array}$ \\
\hline $\mathrm{R}_{5}$ & $\begin{array}{l}\text { Nezadovoljenje očekivanja od strane } \\
\text { dobavljača (isporučeni materijal nije } \\
\text { odgovarajućeg kvaliteta, kašnjenje u } \\
\text { isporuci materijala) }\end{array}$ \\
\hline $\mathrm{R}_{6}$ & $\begin{array}{l}\text { Prekoračenje utroška finansijskih sredstava } \\
\text { (troškovi projekta premašuju dodeljena } \\
\text { sredstva) }\end{array}$ \\
\hline $\mathrm{R}_{7}$ & $\begin{array}{l}\text { Nedostatak vremena (prekratak vremenski } \\
\text { rok izvršenja logističkih aktivnosti) }\end{array}$ \\
\hline $\mathrm{R}_{8}$ & $\begin{array}{l}\text { Loše marketinške procene } \\
\text { (predimenzionirano predviđanje } \\
\text { buduće prodaje, pogrešna procena po } \\
\text { pitanju prodaje inoviranih proizvoda) }\end{array}$ \\
\hline $\mathrm{R}_{9}$ & $\begin{array}{l}\text { Resursni rizik (nekvalifikovano } \\
\text { osoblje, nedostatak opreme i } \\
\text { neophodnog materijala) }\end{array}$ \\
\hline $\mathrm{R}_{10}$ & $\begin{array}{l}\text { Promene na tržištu (inflacija, deflacija, } \\
\text { promena kursa) }\end{array}$ \\
\hline
\end{tabular}

Tabela 1. Rizični događaji logističkih projekata

Nivo 1

Početni korak u rangiranju logističkih projekata na osnovu rizika jeste utvrđivanje težinskih koeficijenata rizičnih događaja. 
U tu svrhu, menadžeri logistike i menadžeri upravljanja rizika u preduzeću ocenili su jačinu i uticaj rizičnih događaja. Ocenjivanje rizičnih događaja izvršeno je na osnovu devetostepene Satijeve skale i prikazano u Tabeli 2.

Konačni prioritet za Nivo $1: \mathrm{R}_{8}(0,2884) ; \mathrm{R}_{1}(0,2102)$; $\mathrm{R}_{6}(0,1517) ; \mathrm{R}_{4}(0,1096) ; \mathrm{R}_{7}(0,0789) ; \mathrm{R}_{9}(0,0566) ; \mathrm{R}_{5}$ $(0,0402) ; \mathrm{R}_{2}(0,0289) ; \mathrm{R}_{3}(0,0202) ; \mathrm{R}_{10}(0,0154)$.

\section{Nivo 2}

Posle ocenjivanja važnosti i određivanja težinskih koeficijenata rizičnih događaja, menadžeri logistike, ali i menadžeri upravljanja rizika, vrše ocenjivanje logističkih projekata na osnovu svakog razmatranog rizičnog događaja.

\begin{tabular}{cccccc}
\hline $\begin{array}{c}\text { Rizični } \\
\text { događaj } \\
\mathrm{R}_{1}\end{array}$ & $\mathrm{P}_{1}$ & $\mathrm{P}_{2}$ & $\mathrm{P}_{3}$ & $\Sigma$ & Rang \\
\hline $\mathrm{P}_{1}$ & 0,2857 & 0,3333 & 0,2732 & 0,8923 & 0,2974 \\
\hline $\mathrm{P}_{2}$ & 0,1429 & 0,1667 & 0,1803 & 0,4899 & 0,1633 \\
\hline $\mathrm{P}_{3}$ & 0,5714 & 0,5000 & 0,5464 & 1,6179 & 0,5393 \\
\hline
\end{tabular}

Tabela 3. Određivanje normalizovanog sopstvenog vektora na osnovu rizičnog događaja $R_{1}$

Konačni prioritet za rizični događaj $\mathrm{R}_{1}: \mathrm{P}_{3}(0,5393)$; $\mathrm{P}_{1}(0,2974) ; \mathrm{P}_{2}(0,1633)$.

\begin{tabular}{cccccc}
\hline $\begin{array}{c}\text { Rizični } \\
\text { događaj } \\
\mathrm{R}_{2}\end{array}$ & $\mathrm{P}_{1}$ & $\mathrm{P}_{2}$ & $\mathrm{P}_{3}$ & $\Sigma$ & Rang \\
\hline $\mathrm{P}_{1}$ & 0,3003 & 0,2857 & 0,3750 & 0,9610 & 0,3203 \\
\hline $\mathrm{P}_{2}$ & 0,6006 & 0,5714 & 0,5000 & 1,6720 & 0,5573 \\
\hline $\mathrm{P}_{3}$ & 0,0991 & 0,1429 & 0,1250 & 0,3670 & 0,1223 \\
\hline
\end{tabular}

Tabela 4. Određivanje normalizovanog sopstvenog vektora na osnovu rizičnog događaja $R_{2}$

Konačni prioritet za rizični događaj $\mathrm{R}_{2}: \mathrm{P}_{2}(0,5573)$; $\mathrm{P}_{1}(0,3203) ; \mathrm{P}_{3}(0,1223)$.

\begin{tabular}{cccccc}
\hline $\begin{array}{c}\text { Rizični } \\
\text { događaj } \\
\mathrm{R}_{3}\end{array}$ & $\mathrm{P}_{1}$ & $\mathrm{P}_{2}$ & $\mathrm{P}_{3}$ & $\Sigma$ & Rang \\
\hline $\mathrm{P}_{1}$ & 0,6536 & 0,5556 & 0,6928 & 1,9020 & 0,6340 \\
\hline $\mathrm{P}_{2}$ & 0,1307 & 0,1111 & 0,0762 & 0,3180 & 0,1060 \\
\hline $\mathrm{P}_{3}$ & 0,2157 & 0,3333 & 0,2309 & 0,7800 & 0,2600 \\
\hline
\end{tabular}

Tabela 5. Određivanje normalizovanog sopstvenog vektora na osnovu rizičnog događaja $\mathrm{R}_{3}$

Konačni prioritet za rizični događaj $\mathrm{R}_{3}: \mathrm{P}_{1}(0,6340)$; $\mathrm{P}_{3}(0,2600) ; \mathrm{P}_{2}(0,1060)$.

\begin{tabular}{cccccc}
\hline $\begin{array}{c}\text { Rizični } \\
\text { događaj } \\
\mathrm{R}_{4}\end{array}$ & $\mathrm{P}_{1}$ & $\mathrm{P}_{2}$ & $\mathrm{P}_{3}$ & $\Sigma$ & Rang \\
\hline $\mathrm{P}_{1}$ & 0,5464 & 0,5000 & 0,5714 & 1,6179 & 0,5393 \\
\hline $\mathrm{P}_{2}$ & 0,1803 & 0,1667 & 0,1429 & 0,4899 & 0,1633 \\
\hline $\mathrm{P}_{3}$ & 0,2732 & 0,3333 & 0,2857 & 0,8923 & 0,2974 \\
\hline
\end{tabular}

Tabela 6. Određivanje normalizovanog sopstvenog vektora na osnovu rizičnog događaja $\mathrm{R}_{4}$

Konačni prioritet za rizični događaj $\mathrm{R}_{4}: \mathrm{P}_{1}(0,5393)$; $\mathrm{P}_{3}(0,2974) ; \mathrm{P}_{2}(0,1633)$.

\begin{tabular}{cccccc}
\hline $\begin{array}{c}\text { Rizični } \\
\text { događaj } \\
\mathrm{R}_{5}\end{array}$ & $\mathrm{P}_{1}$ & $\mathrm{P}_{2}$ & $\mathrm{P}_{3}$ & $\Sigma$ & Rang \\
\hline $\mathrm{P}_{1}$ & 0,1667 & 0,1803 & 0,1429 & 0,4899 & 0,1633 \\
\hline $\mathrm{P}_{2}$ & 0,5000 & 0,5464 & 0,5714 & 1,6179 & 0,5393 \\
\hline $\mathrm{P}_{3}$ & 0,3333 & 0,2732 & 0,2857 & 0,8923 & 0,2974 \\
\hline
\end{tabular}

Tabela 7. Određivanje normalizovanog sopstvenog vektora na osnovu rizičnog događaja $\mathrm{R}_{5}$

Konačni prioritet za rizični događaj $\mathrm{R}_{5}: \mathrm{P}_{2}(0,5393)$; $\mathrm{P}_{3}(0,2974) ; \mathrm{P}_{1}(0,1633)$.

\begin{tabular}{cccccc}
\hline $\begin{array}{c}\text { Rizični } \\
\text { događaj } \\
\mathrm{R}_{6}\end{array}$ & $\mathrm{P}_{1}$ & $\mathrm{P}_{2}$ & $\mathrm{P}_{3}$ & $\Sigma$ & Rang \\
\hline $\mathrm{P}_{1}$ & 0,7042 & 0,8000 & 0,5714 & 2,0757 & 0,6919 \\
\hline $\mathrm{P}_{2}$ & 0,1197 & 0,1333 & 0,2857 & 0,5388 & 0,1796 \\
\hline $\mathrm{P}_{3}$ & 0,1761 & 0,0667 & 0,1429 & 0,3856 & 0,1285 \\
\hline
\end{tabular}

Tabela 8. Određivanje normalizovanog sopstvenog vektora na osnovu rizičnog događaja $\mathrm{R}_{6}$ 


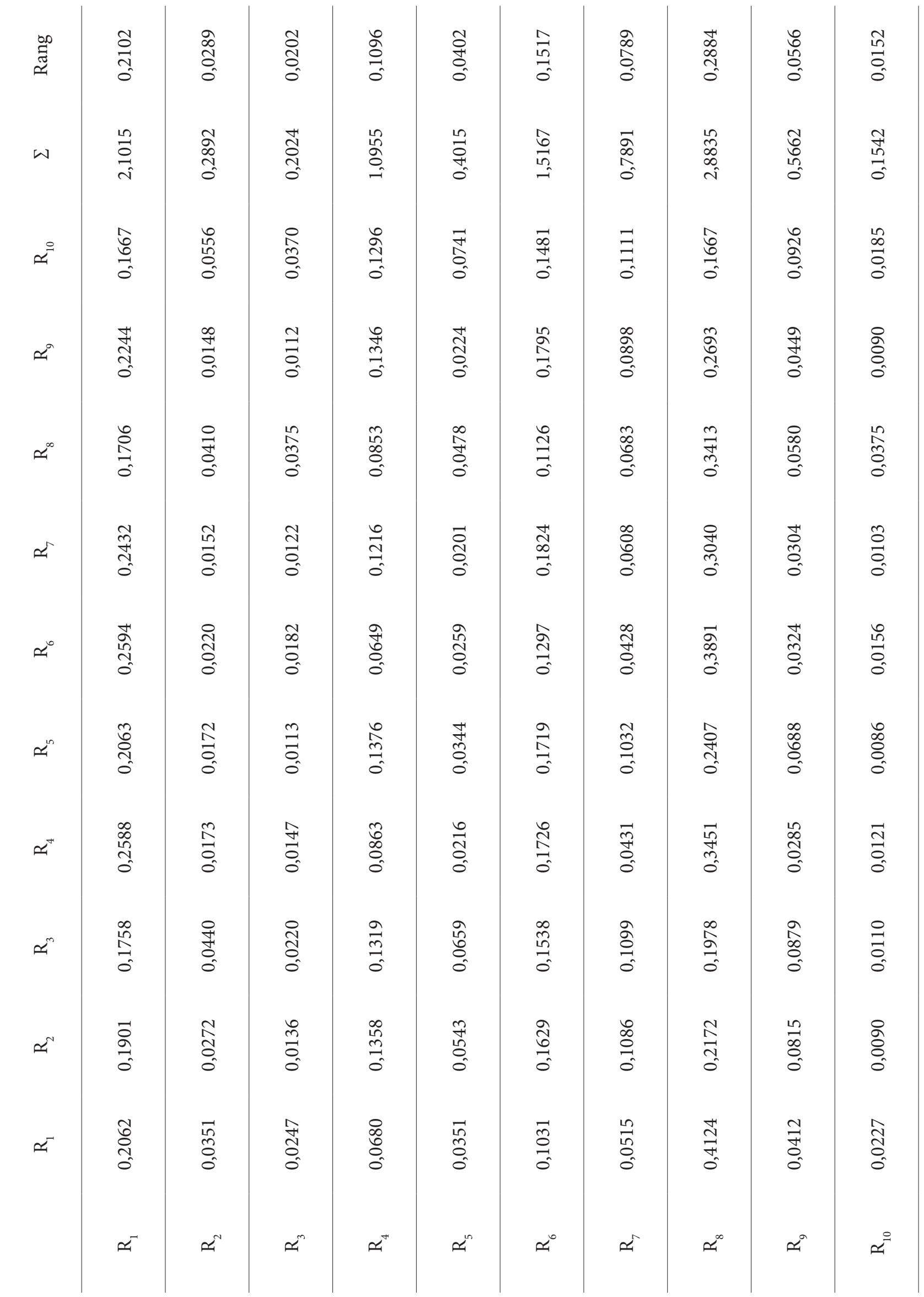

Tabela 2. Određivanje normalizovanog sopstvenog vektora 
Konačni prioritet za rizični događaj $\mathrm{R}_{6}: \mathrm{P}_{1}(0,6919)$; $\mathrm{P}_{2}(0,1796) ; \mathrm{P}_{3}(0,1285)$.

\begin{tabular}{cccccc}
\hline $\begin{array}{c}\text { Rizični } \\
\text { događaj } \\
\mathrm{R}_{7}\end{array}$ & $\mathrm{P}_{1}$ & $\mathrm{P}_{2}$ & $\mathrm{P}_{3}$ & $\Sigma$ & Rang \\
\hline $\mathrm{P}_{1}$ & 0,1667 & 0,1429 & 0,1803 & 0,4899 & 0,1633 \\
\hline $\mathrm{P}_{2}$ & 0,3333 & 0,2857 & 0,2732 & 0,8923 & 0,2974 \\
\hline $\mathrm{P}_{3}$ & 0,5000 & 0,5714 & 0,5464 & 1,6179 & 0,5393 \\
\hline
\end{tabular}

Tabela 9. Određivanje normalizovanog sopstvenog vektora na osnovu rizičnog događaja $\mathrm{R}_{7}$

Konačni prioritet za rizični događaj $\mathrm{R}_{7}: \mathrm{P}_{3}(0,5393)$; $\mathrm{P}_{2}(0,2974) ; \mathrm{P}_{1}(0,1633)$.

\begin{tabular}{cccccc}
\hline $\begin{array}{c}\text { Rizični } \\
\text { događaj } \\
\mathrm{R}_{8}\end{array}$ & $\mathrm{P}_{1}$ & $\mathrm{P}_{2}$ & $\mathrm{P}_{3}$ & $\Sigma$ & Rang \\
\hline $\mathrm{P}_{1}$ & 0,6536 & 0,5556 & 0,6928 & 1,9020 & 0,6340 \\
\hline $\mathrm{P}_{2}$ & 0,1307 & 0,1111 & 0,0762 & 0,3180 & 0,1060 \\
\hline $\mathrm{P}_{3}$ & 0,2157 & 0,3333 & 0,2309 & 0,7800 & 0,2600 \\
\hline
\end{tabular}

Tabela 10. Određivanje normalizovanog sopstvenog vektora na osnovu rizičnog događaja $\mathrm{R}_{8}$

Konačni prioritet za rizični događaj $\mathrm{R}_{8}: \mathrm{P}_{1}(0,6340)$; $\mathrm{P}_{3}(0,2600) ; \mathrm{P}_{2}(0,1060)$.

\begin{tabular}{cccccc}
\hline $\begin{array}{c}\text { Rizični } \\
\text { događaj } \\
\mathrm{R}_{9}\end{array}$ & $\mathrm{P}_{1}$ & $\mathrm{P}_{2}$ & $\mathrm{P}_{3}$ & $\Sigma$ & Rang \\
\hline $\mathrm{P}_{1}$ & 0,2857 & 0,2732 & 0,3333 & 0,8923 & 0,2974 \\
\hline $\mathrm{P}_{2}$ & 0,5714 & 0,5464 & 0,5000 & 1,6179 & 0,5393 \\
\hline $\mathrm{P}_{3}$ & 0,1429 & 0,1803 & 0,1667 & 0,4899 & 0,1633 \\
\hline
\end{tabular}

Tabela 11. Određivanje normalizovanog sopstvenog vektora na osnovu rizičnog događaja $\mathrm{R}_{9}$

Konačni prioritet za rizični događaj $\mathrm{R}_{9}: \mathrm{P}_{2}(0,5393)$; $\mathrm{P}_{1}(0,2974) ; \mathrm{P}_{3}(0,1633)$.

\begin{tabular}{cccccc}
\hline $\begin{array}{c}\text { Rizični } \\
\text { događaj } \\
\mathrm{R}_{9}\end{array}$ & $\mathrm{P}_{1}$ & $\mathrm{P}_{2}$ & $\mathrm{P}_{3}$ & $\Sigma$ & Rang \\
\hline $\mathrm{P}_{1}$ & 0,5464 & 0,5714 & 0,5000 & 1,6179 & 0,5393 \\
\hline $\mathrm{P}_{2}$ & 0,2732 & 0,2857 & 0,3333 & 0,8923 & 0,2974 \\
\hline $\mathrm{P}_{3}$ & 0,1803 & 0,1429 & 0,1667 & 0,4899 & 0,1633 \\
\hline
\end{tabular}

Tabela 12. Određivanje normalizovanog sopstvenog vektora na osnovu rizičnog događaja $\mathrm{R}_{10}$

Konačni prioritet za rizični događaj $\mathrm{R}_{10}: \mathrm{P}_{1}(0,5393)$; $\mathrm{P}_{2}(0,2974) ; \mathrm{P}_{3}(0,1633)$.

Nivo 3

Poslednji korak u rangiranju logističkih projekata primenom AHP metode podrazumeva upoređivanje logističkih projekata na osnovu svih razmatranih rizičnih događaja. Sinteza problema rangiranja projekata jednaka je zbiru proizvoda težina u okviru posmatranog rizičnog događaja:

Logistički projekat $\mathrm{P}_{1}$

$T_{P 1}=R_{1} * R_{1} P_{1}+R_{2} * R_{2} P_{1}+R_{3} * R_{3} P_{1}+R_{4} * R_{4} P_{1}+R_{5} * R_{5} P_{1}+R_{6} * R_{6} P_{1}$
$+R_{7} * R_{7} P_{1}+R_{8} * R_{8} P_{1}+R_{9} * R_{9} P_{1}+R_{10} * R_{10} P_{1}$

$T_{P 1}=0,2102 * 0,2974+0,0289 * 0,3203+0,0202 * 0,6340+0,1096$ $* 0,5393+0,0402 * 0,1633+0,1517 * 0,6919+0,0789 * 0,1633+0,28$ $84 * 0,6340+0,0566 * 0,2974+0,0154 * 0,5393=0,4760$

Logistički projekat $\mathrm{P}_{2}$

$T_{P 2}=R_{1} * R_{1} P_{2}+R_{2} * R_{2} P_{2}+R_{3} * R_{3} P_{2}+R_{4} * R_{4} P_{2}+R_{5} * R_{5} P_{2}+R_{6} * R_{6} P_{2}+$

$R_{7} * R_{7} P_{2}+R_{8} * R_{8} P_{2}+R_{9} * R_{9} P_{2}+R_{10} * R_{10} P_{2}$

$T_{P 2}=0,2102 * 0,1633+0,0289 * 0,5573+0,0202 * 0,1060+0,1096$ * $0,1633+0,0402 * 0,5393+0,1517 * 0,1796+0,0789 * 0,2974+0,28$ $84 * 0,1060+0,0566 * 0,5393+0,0154 * 0,2974=0,2085$

Logistički projekat $\mathrm{P}_{3}$

$T_{P 3}=R_{1}{ }^{*} R_{1} P_{3}+R_{2} * R_{2} P_{3}+R_{3} * R_{3} P_{3}+R_{4} * R_{4} P_{3}+R_{5} * R_{5} P_{3}+R_{6} * R_{6} P_{3}$ $+R_{7} * R_{7} P_{3}+R_{8} * R_{8} P_{3}+R_{9} * R_{9} P_{3}+R_{10} * R_{10} P_{3}$

$T_{P 3}=0,2102 * 0,5393+0,0289 * 0,1223+0,0202 * 0,2600+0,1096 *$ $0,2974+0,0402 * 0,2974+0,1517 * 0,1285+0,0789 * 0,5393+0,28$ $84 * 0,2600+0,0566 * 0,1633+0,0154 * 0,1633=0,3154$

Ukupni rang logističkih projekata u odnosu na globalni cilj je: $\mathrm{P}_{1}(0,4760) ; \mathrm{P}_{3}(0,3154) ; \mathrm{P}_{2}(0,2085)$. Sveobuhvatna sinteza rangiranja logističkih projekata može biti prikazana kao:

$$
T_{P 1}>T_{P 3}>T_{P 2}
$$

Savremeno doba je doba informacionih tehnologija. U cilju uspešnog poslovanja na turbulentnom tržištu, privredni subjekti u svom poslovanju moraju da koriste 
razne softvere i informacione alate za poboljšanje efikasnosti i efektivnosti preduzeća radi ostvarenja profita. U skladu sa tim, rangiranje logističkih projekata na osnovu rizika izvršeno je i softverskim alatom Expert Choice 11.

Rezultati istraživanja prikazani su na Slici 2.

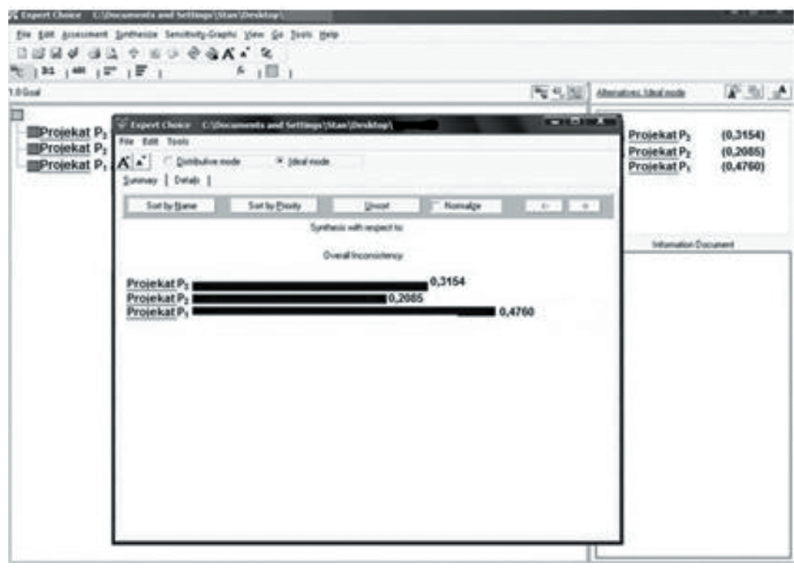

Slika 2. Rezultati istraživanja primenom Expert Choice-a

Analiza logističkih projekata na osnovu rizika potvrdila je rezultate klasične primene AHP metode. Ukupni rang razmatranih logističkih projekata na osnovu obima i veličine rizika primenom softverskog paketa Expert Choice moguće je prikazati kao: $\mathrm{P}_{1}(0,4760) ; \mathrm{P}_{3}(0,3154)$; $\mathrm{P}_{2}(0,2085)$.

\section{ZAKLJUČAK}

Istraživački deo ovog rada prikazuje rangiranje logističkih projekata na osnovu rizika. $U$ radu su analizirana tri logistička projekta koja imaju najveću važnost u preduzeću na osnovu 10 mogućih rizičnih događaja.

Najvažniji rizični događaj u analiziranom privrednom subjektu je rizični događaj $R_{8}$ - loše marketinške procene sa ocenom 0,2884 . Sa druge strane, rizični događaj sa najmanjim uticajem je rizični događaj $\mathrm{R}_{10}$ - promene na tržištu sa ocenom 0,0154 .

$\mathrm{Na}$ osnovu rizičnog događaja iznenadne promene u planu proizvodnje, najbolja opcija, tj. opcija sa najmanjim mogućim rizikom je logistički projekat $\mathrm{P}_{3}$. Sa druge strane, analiza alternativa na osnovu rizičnog događaja kvarovi tehničkih sredstava pokazala je da je projekat sa najmanjom šansom za kvar tehničkih sredstava logistički projekat $\mathrm{P}_{2}$. Analiza rizičnog događaja iznenadno povećanje potražnje pokazuje da je najmanje rizičan logistički projekat $\mathrm{P}_{1}$. Pored toga, u pogledu loše komunikacije najmanja šansa za rizik zabeležena je kod logističkog projekta $\mathrm{P}_{1}$. Dobavljači kod logističkog projekta $\mathrm{P}_{2}$ ocenjeni su kao najstabilniji, te je rizik kod ovog projekta u pogledu nezadovoljenja očekivanja od strane dobavljača, u poređenju sa drugim logističkim projektima, na najnižem nivou. Najpovoljniji logistički projekat sa aspekta rizičnog događaja prekoračenje utroška finansijskih sredstava je projekat $\mathrm{P}_{1}$, dok je sa aspekta rizičnog događaja nedostatak vremena najmanji rizik zabeležen kod logističkog projekta $\mathrm{P}_{3}$. Sa aspekta rizičnog događaja loše marketinške procene, koji je ocenjen kao najuticajniji rizični događaj na preduzeće, najpovoljniji je logistički projekat $\mathrm{P}_{1}$. Logistički projekat $\mathrm{P}_{2}$ je najpovoljniji u pogledu rizičnog događaja resursni rizik. Sa druge strane, najmanji uticaj promene na tržištu imaju na logistički projekat $\mathrm{P}_{1}$.

Završni korak AHP metode podrazumeva rangiranje logističkih projekata na osnovu rizika, sagledavajući sve rizične događaje. Rezultati su pokazali da je najmanje rizičan logistički projekat $P_{1}$ sa ocenom 0,4760 , više je rizičan logistički projekat $\mathrm{P}_{3}$ sa ocenom 0,3154 , dok je najrizičniji logistički projekat $\mathrm{P}_{2}$ sa ocenom 0,2085.

Informacione tehnologije predstavljaju osnovu poslovanja uspešnih preduzeća. Radi efikasnije analize i rangiranja logističkih projekata na osnovu rizika, korišćen je softverski paket Expert Choice.

Primena softvera potvrdila je rezultate istraživanja i u velikoj meri unapredila poslovanje preduzeća davanjem efikasne osnove za uspešno upravljanje rizicima logističkih projekata, kako bi se isti izvršili na efektivan način i doprineli dostizanju kompanijskih ciljeva.

\section{LITERATURA}

[1] Regodić, D. (2011). Logistika, Beograd: Univerzitet Singidunum.

[2] Drljača, M., \& Bešker, M. (2010). Održivi uspjeh i upravljanje rizicima poslovanja, XIV savjetovanje SQM, 14-15. septembar 2010. (str. 1-16). Podgorica, Crna Gora: Centar za kvalitet, Mašinski fakultet.

[3] Kirin, S., Sedmak, A., Grubić Nešić, L., \& Ćorić, I. (2012). Upravljanje rizikom projekata u kompleksnom petrohemijskom sistemu. Hemijska industrija. 66 (1), 135-148. DOI: 10.2298/ HEMIND110709052K.

[4] Jovanović, P., Jovanović, F., \& Berić, I. (2014). Upravljanje rizikom vojnih projekata i poduhvata. Vojno delo. 66(4), 42-48. DOI: 10.5937/vojdelo1404042J. 
[5] Bajrami, Š. (2014). ELECTRE i AHP - sistemi za podršku višekriterijumskom odlučivanju, XIII međunarodni naučno-stručni simpozijum INFOTEH-JAHORINA, 19-21. mart 2014. (str. 599-604). Istočno Sarajevo, Bosna i Hercegovina: Elektrotehnički fakultet.

[6] Draginčić, J., Vranešević, M., \& Srđević, B. (2012). Grupno vrednovanje AHP softvera za podršku odlučivanju u poljoprivredi. Letopis naučnih radova Poljoprivrednog fakulteta. 36(1), 26-35.
[7] Industry Computer Software Expert Choice, Inc. (2016). Expert Choice (Version 11). Retrieved 10.02.2017. from http://expertchoice.com/academic-program/for-students/

[8] Srđević, B., Srđević, Z., \& Suvočarev, K. (2007). Kompjuterski alati i sistemi za podršku u poljoprivredi. Letopis naučnih radova Poljoprivrednog fakulteta. 31(1), 55-64.

\title{
THE USAGE OF THE AHP METHODOLOGY FOR THE RISK-BASED RANKING OF LOGISTICS-RELATED PROJECTS
}

\begin{abstract}
:
Modern business conditions include strong competition. Accordingly, to succeed in a turbulent market it is necessary to perform tasks better and more effectively than the competition. Logistics is one of the most important of the continent which is largely dependent on the success of certain companies in the market. Logistic projects represent a modern tool for performing logistics activities. These projects are often very numerous and require adequate management. The big problem in the management of logistics projects are risks. The subject of the research work is reflected in the ranking of logistics projects on the basis of risk using the AHP method and software package Expert Choice 11th. The aim of the research involves the ranking of logistics projects based on defined risk events, determining the level of risk in global logistics projects and ranked on the basis of the same.
\end{abstract}

\section{Keywords:}

risk, project logistics, management, AHP method, software Expert Choice 11. 